\title{
Resource linkages and capability development
}

\author{
Chia-Wen Hsu ${ }^{a, b, 1}$, Homin Chen ${ }^{a, *}$, Lichung Jen ${ }^{\text {a, } 2}$ \\ ${ }^{a}$ Department of International Business, National Taiwan University, NO. 85, Sec. 4, Roosevelt Road, Taipei 106, Taiwan \\ ${ }^{\mathrm{b}}$ Department of International Business, Yuan-Ze University, No. 135, Yuan-Tung Road, Chung-Li, Taoyuan 320, Taiwan
}

Received 25 March 2006; received in revised form 6 March 2007; accepted 6 December 2007

Available online 10 January 2008

\begin{abstract}
In this paper, we examine the different resource linkages sought by manufacturing firms through strategic alliance. We look closely at the impact of manufacturing activities on choice of resource linkage. Using a sample of Taiwanese firms, we found that product development ability and marketing distribution channels are the top priority resource linkages that Taiwanese manufacturing firms seek to establish. The authors also found it interesting that marketing know-how was not a resource commonly sought by Original Design and Manufacturing (ODM) firms, nor by Own-Brand Manufacturing (OBM) firms. Some implications are further discussed. Instead of outsourcing production to external suppliers, Taiwanese OBM firms remained committed to manufacturing as a core competence when they established their own brands overseas.
\end{abstract}

(C) 2007 Elsevier Inc. All rights reserved.

Keywords: Resource linkages; Strategic alliance; Marketing distribution channels; Product development ability; Marketing know-how

\section{Introduction}

Strategic alliances have gained increasing popularity across all business sectors in recent years. A strategic alliance is a cooperative agreement between firms in which partners may contribute resources, technology or firm-specific assets (Chen \& Chen, 2002, 2003; Murray \& Kotabe, 2005). Through strategic alliance, partners can learn or acquire from each other the strategic capabilities that are not available within their own organizations (Nohria \& Garcia-Pont, 1991). Such alliances may also contribute to business efficiency and be an important source of sustainable competitive advantage (Dyer \& Singh, 1998). For Newly Industrializing Economy (NIE) firms like those from Taiwan, forming strategic alliances with advanced country firms is an important channel for gaining market access and new technologies (Chen \& Chen, 2003). In particular, use of such alliance activity can be critical for Small and Medium-sized Enterprises (SMEs) to improve their competitive positions (Arend, 2006; Beekman \& Roobinson, 2004).

\footnotetext{
* Corresponding author. Tel.: +886 233664969 ; fax: +886223641843.

E-mail addresses: d92724010@ntu.edu.tw (C.-W. Hsu), hmchen@management.ntu.edu.tw (H. Chen), lichung@management.ntu.edu.tw (L. Jen).

${ }^{1}$ Tel.: +886233664969

2 Tel.: +886233664983 .
}

We are now seeing increasing numbers of Asian brand names successfully establish a presence in the world market. In 2004, eight Asian companies ranked among the world's top 100 most valuable brands. By 2006 that number has increased to eleven, most being Japanese (Business Week, 2006). Many of these firms were probably unheard of 40 years ago. Beginning in the mid-1980s, Japanese companies began to develop alliances with Western partners to create greater competitive synergy and leverage their brand presence. Examples of these alliances include Toshiba's strategic partnership with Motorola, and Canon's partnerships and joint ventures with Texas Instruments, Hewlett-Packard, Apple, and Motorola. As a result of establishing strong brand names, Japanese companies have created immense economic leverage for themselves (Wee, 1994).

In fact, in the initial phase Japan produced and sold many of its products through American and European distributors, very often under the distributors' brand names. They had to be camouflaged by using American and European brand names (Kotler, Fahey, \& Jatuscripitak, 1985). As Japanese products improved in quality and gained market acceptance in the 1970s, Japanese companies began to embark systematically and relentlessly on brand development and image building, with the result that Japan has since established strong brand names in the world market (Wee, 1994). Following Japan's success, other Asian NIEs such as Korea and Taiwan have been employing the same 
trajectories. Firms begin with the development of a strong brand in home markets, then, utilize Original Equipment Manufacturing (OEM) brands to expand and become familiar with international markets (Cheng, Blankson, Wu, \& Chen, 2005).

Compared to the other Asian NIEs, the South Koreans are probably the most successful in the area of brand development with their three brands, Samsung, Hyundai and LG, making the top 100 list in 2006. In pursuing a monolithic brand strategy like the Japanese, the South Koreans have demonstrated that they also can be successful in the world market. Firms from neighboring NIEs, such as Acer from Taiwan and Haier from China, are likely to follow in their footsteps (Hobday, 1995, 2000).

Hobday (1995) argues that the development of NIEs' manufacturing models is created by leverage strategies in terms of expanding manufacturing competences, from the simplest Original Equipment Manufacturing to more complex activities (Original Design and Manufacturing (ODM)), to fully fledged product development, manufacturing and marketing (or 'OwnBrand Manufacturing' (OBM)). Most firms will pursue this trajectory unless they lack the resources or skills to progress to the next stage.

Many Taiwanese firms have inserted themselves in global commodity chains through OEM and then ODM contracting. Most of these firms provide OEM or ODM services for international brand vendors. Few of them have "broken through" into Own-Brand Manufacturing (Cheng et al., 2005; Mathews, 1997; Yue-Ming, 2005). Even today, Taiwanese firms still rely heavily on producing products that are sold under brand names of large multinational companies (MNCs). For example, Taiwan is wellknown for making products for brands such as Dell, HewlettPackard, and Apple. Despite Taiwan's heavy manufacturing base, there are few international brands of Taiwanese origin in the world market today. Fortunately, more and more Taiwanese companies are beginning to realize the importance of branding. Firms such as Acer, BenQ, and Asus are already investing a significantly higher level of resources into brand development.

The purpose of this article is to determine the most essential resource linkages for Taiwanese manufacturing firms entering into strategic alliances. We classify resources into four categories, namely, cost reduction, product development ability, marketing know-how and marketing distribution channels. We show that the manufacturing model (OEM/ODM/OBM) determines the type of resource linkages sought by a firm when it is allying with foreign partners to enhance its competitive strength.

The body of the paper is organized as follows. In the next section, the literature and theoretical development are discussed, and several hypotheses are formulated. This is followed by descriptions of the methodology and data used in the empirical study, and presentation of the results. Finally, the conclusions and implications drawn from this study are presented along with limitations and future research possibilities.

\section{Theoretical development and hypotheses}

Many firms in East Asian countries follow the "Reverse Value Chain" strategy that was developed by Wong (1999) based on Hobday's work on OEM-ODM-OBM migration strategy (Hobday, 1995, 2000). The notion of the concept is that latecomers pursue a certain strategy to develop technological capabilities: first they start developing process capability, followed by product design capability and finally new product creation/brand capabilities. This is a reversal of the normal sequence of value chain activities pursued by large, established high-tech firms in advanced countries (Wong, 1999).

Interorganizational relationship formation can help firms create value by combining various resources (Barringer \& Harrison, 2000). Through strategic alliance, a firm can gain access to desired strategic capabilities by linking to a partner with complementary capabilities or by pooling its internal resources with a partner that possesses similar capabilities (Nohria \& Garcia-Pont, 1991; Porter \& Baden-Fuller, 1986). This has very important implications for Taiwanese firms, as they are very successful at learning from foreign strategic alliance partners (Chen \& Chen, 2002, 2003).

Alliances create synergies between resources that enhance or reshape competition in the market. Such alliances have enabled many Taiwanese firms to expand manufacturing competences from OEM to ODM or even OBM within the last two decades. Firms tend to have a portfolio of reasons for alliance formation, such as cost minimization, economies of scale, gaining access to a particular resource, risk and cost sharing, gaining access to foreign markets, product/service development, learning, speed to market, flexibility, collective lobbying, and neutralizing or blocking competitors (Barringer \& Harrison, 2000; Doz \& Hamel, 1998). Organizations attempt to improve competitiveness by developing and bringing together new sources of technologies and skills, often resulting in the formation of a new organizational structure (Hamel, 1991; Prahalad \& Hamel, 1990; Yoshino \& Rangan, 1995).

Global alliances allow firms to move into international markets despite fierce global competition. They further enable firms to acquire and internalize skills from alliance partners as suggested by the resource-based view of alliance formation (Glaister \& Buckly, 1996; Inkpen, 1998). For developing countries such as Taiwan, foreign partners are important sources of technological support (Jan \& Hsiao, 2004). Moreover, through global alliance, firms are likely to achieve economies of scale and scope and decrease the risk of performing specific activities in different international locations (Kim \& Park, 2002).

As Crossan and Inkpen (1995) proposed, it is becoming increasingly difficult for organizations to remain self-sufficient in an international business environment. This is one of the driving forces behind the popularization of inter-firm relationship building. By definition, inter-firm alliances involve the establishment of partnerships (Inkpen, 1998). These partnerships allow access to the skills and resources of other parties and provide new opportunities for upgrading and renewing existing capabilities. Alliance partnerships are initiated because they are effective as a strategy to overcome the skill and resource gaps encountered in achieving adaptation to global competitiveness.

Recent literature on inter-firm relationship building has argued that external partners can be very important for a firm's capability development (Andersson, Forsgren, \& Holm, 2002; Holm, Holmstrom, \& Sharma, 2005). These relationships provide 
firms with complementary resources so they can upgrade existing capabilities to compete in markets, and develop products or services to satisfy the needs of their customers. In this way, interfirm relationship building constitutes a stronger means for firms to enhance capabilities than is achievable by firms operating individually. These inter-firm relationships can create a synergetic effect that enhances or reshapes the competitiveness of firms bonded by such relationship building (Chen \& Chen, 1998).

The development of capabilities arising from inter-firm relationships may be stimulated through mutual interdependence with complementary resources (Dyer \& Singh, 1998). Resource linkage through inter-firm relationship building enables the firm to access its partner's resources and leads to the creation of competitive advantage (Chen, Chen, \& Ku, 2004; Nohria \& Garcia-Pont, 1991). The term "resource linkage" is used here to denote connections that are directly or indirectly established through relationships in an overall business network. Within resource linkages, interdependence exists as result of resource interdependencies or resource ties and constellations (Eng, 2005; Hakansson \& Snehota, 1995). A resource linkage provides an immediate means for a firm to achieve capability development.

\subsection{Hypotheses}

In this paper, we focus on Taiwanese firms that are engaged in building inter-firm relationships through resource linkages in order to achieve capability development. The state of existing capability, either recently matured (or available for application), or in a developing stage (needing additional R\&D or marketing know-how), is an influencing factor in selecting partners to form an international strategic alliance. Firms seeking an immediate competitive advantage will establish alliances that provide new but readily available capabilities, while those that desire to remain at the cutting edge of technology and aim for long-term growth, will team up with partners with whom they can develop new technologies. From Taiwan's manufacturing industry, cases for capability evolution through international strategic alliances are provided from firms operating under each of the OEM, ODM and OBM manufacturing models (Hobday, 1995; Mathews, 1997). We will first look at OEM firms.

Over the past decade, Taiwan has established itself as an important "global factory" for a variety of computer related products, integrated circuits, handsets and wireless equipment (Ernst, 2006). A large percentage of the world's desktop PCs was either made in Taiwan or contain a motherboard made by a Taiwanese company (Ernst, 2000). Taiwanese firms have also developed their capacity to provide a package of services across a wide range of value chain activities, and this has helped Taiwan sustain its industrial position as preferred OEM supplier. With the exception of R\&D and marketing, practically all other stages of the value chain can now be undertaken by Taiwan's OEM contractors. Moreover, Taiwanese firms are beginning to shoulder essential coordination functions in global supply chain management for their OEM customers.

A major achievement of Taiwan's "global factory" model has been to combine low-cost production and quick response to change in markets and technology. It was rigorous cost control management and the establishment of a low-cost supply base in China and Southeast Asia that enabled low-cost production. And the strength of quick response was achieved through the development of flexible supplier networks (Chen, Wen, Liu, \& Lin, 2006; Ernst, 2006).

Major international brand vendors enjoy global economies of scale and a brand image advantage. More importantly, these brand vendors are extremely familiar with the end-user market and consumer behavior. Owing to global competition and price pressure from brand vendors, Taiwan's "global factory" model is now experiencing decreasing returns in terms of value added and profit margins. Taiwanese firms typically are under relentless pressure by global brand marketers to reduce cost and time-tomarket for commodity-type products. Taiwanese firms therefore must pay careful attention to cost reduction in order to protect their razor-thin profit margins (Chen et al., 2006; Ernst, 2000; Hobday, 1995; Mathews, 1997).

In principle, OEM firms would be most likely to form an international strategic alliance where they can successfully reduce $R \& D$ costs and manufacturing costs, and increase productivity. Taiwanese OEM firms have attempted to step up their value chain activities into $R \& D$ and product design in order to lessen their dependence on international brand vendors. With the development of product design ability, firms previously operating only as OEM suppliers can shift to offering ODM services, thereby providing both original product design as well as production.

Taiwan manufactures many of the notebook PCs available on the marketplace today. Most of these computers comprise all Taiwanese components re-assembled by American and European companies and sold under these Western brand names. However, the fact that the majority of computers sold under such OEM arrangements were originally designed by Taiwanese companies indicates significantly improved product design ability (Ernst, 2000).

Once a firm's capability reaches a state of maturity, such a firm is likely to attempt to improve or renew this capability in some way. OEM firms can renew their manufacturing capability by accessing advanced R\&D and product design ability through resource linkages (Hobday, 1995; Wee, 1994), thereby gaining the capacity to operate as an ODM manufacturer. Thus we have the following hypothesis:

Hypothesis 1. To upgrade and renew existing capability, cost reduction and product development ability are the top priority resource linkages that an OEM firm seeks to establish.

ODM firms typically provide original product design services along with volume production for a specific contract manufacturing arrangement. Some ODM firms even provide a more complete service to the customer, including component sourcing and global logistics. For example, the large U.S. branded PC marketers can use companies like Quanta and Mitac not only as assemblers, but also as providers of designs, just-in-time delivery, and global logistics services as well (Huang \& Lo, 2003).

ODM firms often lack knowledge about customer needs and entire outsourcing processes, and hence struggle to improve 
their branding capability. As a result, their capability to develop new products and to shape technology road maps and standards remains heavily constrained (Ernst, 2000, 2006). Industrial upgrading through innovation can enhance Taiwanese ODM firms' productivity and enable them to avoid a race to the end that is driven solely by cost competition. It can also serve as a focusing device for Taiwan's attempts to move beyond the "global factory" model and unlock new sources of economic growth (Ernst, 2006). This phenomenon shows how possession of a variety of resource endowments such as technologies, skills and product design ability can create the potential for firms to renew initial capability with complementary capability, and pursue new business opportunities through inter-firm linkages (Dussauge, Garrette, \& Mitchell, 2000).

Taiwanese firms traditionally have a strong competitive advantage in manufacturing and are now gaining prominence in terms of R\&D ability. Focus for many Taiwanese firms has now shifted to the importance of product branding. Such strategies that involve product differentiation and innovation can help the Taiwanese firm to build entry barriers and escape competitive pressure (Berger \& Lester, 2005). In order to increase added value and enhance profitability, ODM firms may choose to expand "downstream" (Ernst, 2000; Li, 2003; Wee, 1994). Generally ODM firms will begin by selling OBM products while essentially still operating as an ODM firm as far as structure and capabilities are concerned. However, sooner or later, upgrading to OBM business requires ODM firms to possess at least basic marketing capabilities in order to reach the end-user with an appropriate marketing mix. Areas such as product promotion and communication with customers become critical to the survival of their brands. The quality of the communication process with effective message content is critical to new product success (Chen, Shen, \& Chiu, 2007). As a result, acquiring marketing know-how becomes a key success factor for ODM firms. Thus we can construct the following hypothesis:

Hypothesis 2. To upgrade and renew existing capability, product development ability and marketing know-how are the top priority resource linkages that an ODM firm seeks to establish.

Taiwanese OEM and ODM firms have always faced the great challenge of defending their profits when dealing with leading international brand vendors that are larger and more powerful. To reduce this dependence and escape narrowing margins and cutthroat competition, Taiwanese firms need to offer unique and difficult-to-replace products and services (Ernst, 2000; Li, 2003; Wee, 1994). Own-Brand Manufacturing is one way to achieve this goal. However, many Taiwanese brands are marketed almost exclusively in Taiwan. Up to now, a small number of Taiwanese firms (e.g., Acer and Tatung) have established well-known brand names abroad and organize their own distribution outlets in developed countries (Hobday, 2000).

To develop a global brand is no easy feat, in particular for a non-Western brand, because of the challenges of negative country of origin perception and regional positions (Cayla, 2007). Firms must decide how to manage brands that span different regions and product lines and control the positioning and marketing of such brands (Beverland, Napoli, \& Lindgreen, 2007; Douglas, Crig, \& Nijssen, 2001). Customer service is a crucial point for branding. A powerful brand marketer has to deliver a high level of customer service and ensure that it provides customer satisfaction. There is significant evidence in the marketing literature that customer satisfaction is an important driver of a firm's profitability (Luo \& Homburg, 2007). To reach their customers, OBM firms need to get access to and/ or even establish their own channels. Branding firms may even require multiple channels to reach their diverse customer base (Myers, Pickersgill, \& Metre, 2004).

Owing to localized brand promotion and a lack of access to international distribution channels, the majority of Taiwanese firms have yet to become key players in the area of international branding. While both product communication and distribution channels are both important to brand marketers (Vorhies \& Morgan, 2005), distribution channels can be the more difficult of the two to establish. Product communication can be achieved through advertising, which can be bought by any firm with an advertising budget. Distribution channels on the other hand can be more difficult to infiltrate. To illustrate this point we can refer to the example of one Taiwanese OBM firm that greatly enhanced its visibility in Europe by pouring in resources to sponsor the European Cup football tournament, but failed to capitalize on the enhanced visibility mainly because they were unable to access the local channels (Chen et al., 2006; Vorhies \& Morgan, 2005). Thus we can construct the following hypothesis:

Hypothesis 3. To upgrade and renew existing capability, marketing distribution channels and then marketing know-how are the first and second priority resource linkages that an OBM firm seeks to establish.

\section{Methodology and data}

\subsection{Data collection and sample}

In order to test the hypotheses posed above, the raw data for this paper was taken from a questionnaire survey conducted by the authors that targeted Taiwanese manufacturing firms with experience in international strategic alliances. Our sample list was drawn from a company file provided by China Credit Information Services (CCIS), a reputable credit-rating company in Taiwan. The CCIS company file contains information on business activities of Taiwanese companies in good standing. From this file, we chose to survey manufacturing companies in the information technology, machinery, and chemical industries in Taiwan. It is recognized in the literature that many major international alliance activities have taken place within these business sectors (Gomes \& Ramaswamy, 1999; Veugelers, 1995). There are 3708 firms in these three industries in the CCIS database. However, our study was to involve making telephone contact with each participating firm, so due to resource constraints we randomly sampled one-third of all firms to arrive at total of 1236 firms that would make up our survey population.

We first contacted top managers of each firm to inquire whether they had engaged in any international strategic alliance 
between 1994 and 2000. Out of this population, 515 firms responded that they had been involved in one or more international strategic alliances. In the case where a firm had been involved in more than one international alliance over the sevenyear period, we requested them to provide information on the most important or largest investment project. Detailed questionnaires were then sent to the project leaders responsible for those alliances.

After several rounds of reminders, a total of 125 valid questionnaires were obtained from the survey, representing a response rate of $24.3 \%$ of the population surveyed. We tested nonresponse bias by comparing early versus late respondents (Armstrong \& Overton, 1977). We also analyzed whether the firms we initially addressed and the responding firms differed in terms of industry. Both tests indicated that there were no nonresponse bias problems. Correspondents were asked to answer a series of questions concerning their international alliance activities. Their responses constitute the basis of this investigation.

\subsection{Variable construction}

In order to determine the resources sought by Taiwanese firms when forming international strategic alliances, we began by asking the respondents which of nine specified types of resources influenced their decision. The types of resources included (1) low labor costs, (2) economies of scale, (3) low R\&D costs, (4) product design technologies, (5) new product development, (6) R\&D competence, (7) marketing know-how, (8) international market entry, and (9) marketing channels. The nine indicators were grouped into four categories; cost reduction, product development ability, marketing know-how and marketing distribution channels (please see Table 1), each of which are essential in enabling OEM-ODM-OBM migration for Taiwanese manufacturing firms (Hobday, 2000). As there were only two possible answers for each indicator - yes or no we developed a grading system to distinguish the extent to which each group of resources was influential in the decision to form an alliance with a foreign firm. 'Yes' was measured as ' 1 ' and no as ' 0 '. The mean value for each group was then compared.

Table 1

Types of resources sought by Taiwanese firms when entering alliances

Types of resources

Cost reduction

Low labor costs

Economies of scale

Low $R \& D$ costs

yes/no

yes/no yes/no

Product development ability

Product design technologies

New product development

$R \& D$ competence

yes/no

yes/no yes/no

Marketing know-how

Marketing know-how

yes/no

Marketing distribution channels

International market entry

Distribution channels
Table 2.1

MANOVA results for three manufacturing models

\begin{tabular}{llll}
\hline MANOVA test statistics & Value & $\begin{array}{l}\text { Approximate } \\
F \text {-statistic }\end{array}$ & $\begin{array}{l}\text { Significance of } \\
F \text {-statistic }\end{array}$ \\
\hline Wilk's lambda & 0.868 & 2.151 & 0.03 \\
Pillai's trace & 0.136 & 2.157 & 0.03 \\
Hotelling-Lawley's trace & 0.148 & 2.145 & 0.03 \\
\hline
\end{tabular}

Additionally, we categorized all Taiwanese firms into three groups, according to the services they provide (OEM, ODM and OBM). A firm's activities in the one area had to reach or exceed $50 \%$ in order to be classified as operating under that manufacturing model. For example, if a Taiwanese firm's production profiles were $30 \%$ in the OEM category, $60 \%$ in the ODM category, and $10 \%$ in the OBM category, then the firm would be categorized into the ODM group. There were no firms that had an even split of $50 \%$ of two different services and there was only one firm in which there was no single percentage above fifty. For this case the proportions were 30\% OEM, 30\% ODM, and $40 \%$ OBM, and the decision was made for the firm to be classified into the OBM group. A firm's classification implies its current manufacturing model.

We then employed a multivariate analysis of variance (MANOVA) to identify the differences in resource linkage among Taiwanese firms of different manufacturing models. Additionally, a univariate analysis of variance (ANOVA) was used to confirm that Taiwanese firms at different stages of the manufacturing model had engaged in particular forms of resource linkage. Basically, MANOVA compares the three groups of firms jointly, whereas ANOVA makes pair-wise comparisons.

\section{Empirical results}

We conducted a multivariate analysis of variance (MANOVA) on Taiwanese international strategic alliance profiles. These alliance profiles were drawn up in two dimensions, namely: 1) the firm's manufacturing model, and 2) resource linkages. The results of the analysis presented in Table 2.1 indicate that overall differences among the three groups of firms are statistically significant in terms of Wilk's lambda (0.868), Pillai's trace (0.136) or Hotelling-Lawley's trace (0.148). It can therefore be seen that firms of different manufacturing models tend to have different resource linkages.

We also conducted a univariate analysis of variance (ANOVA) to test whether Taiwanese firms at different stages of the manufacturing model had engaged in particular forms of resource linkage. Table 2.2 shows that the OEM firms have a higher score when it comes to making a resource linkage for the sake of cost reduction and product development ability. (The statistical tests show that product development ability has the highest score, followed by cost reduction, then marketing distribution channels, and finally marketing know-how; all pair-wise comparisons among the four resource linkages are significant.) This result is consistent with the observation that OEM firms may face intense global competition and resulting pressure from international brand vendors to lower manufacturing costs. Even more apparent, 
Table 2.2

Standard means and mean comparisons for three manufacturing models

\begin{tabular}{|c|c|c|c|c|c|c|}
\hline \multirow[t]{2}{*}{ Dependent variables } & \multicolumn{3}{|c|}{ Variable means } & \multirow{2}{*}{\multicolumn{2}{|c|}{$\begin{array}{l}\text { Multiple comparisons for } \\
\text { three manufacturing } \\
\text { models }\end{array}$}} & \multirow{2}{*}{$\begin{array}{l}\text { Mean } \\
\text { difference }\end{array}$} \\
\hline & OEM & ODM & $\overline{\text { OBM }}$ & & & \\
\hline \multirow[t]{2}{*}{ Cost reduction $(\mathrm{CR})$} & 0.391 & 0.246 & 0.259 & OEM & ODM & $0.145^{* *}$ \\
\hline & & & & ODM & OBM & -0.013 \\
\hline \multirow[t]{2}{*}{ Product development ability (PDA) } & 0.565 & 0.384 & 0.432 & OEM & ODM & $0.181 * *$ \\
\hline & & & & & OBM & $0.133^{*}$ \\
\hline & & & & & OBM & 0.002 \\
\hline & & & & OEM & OBM & 0.001 \\
\hline \multirow[t]{3}{*}{ Marketing distribution channels (MDC) } & 0.297 & 0.351 & 0.526 & OBM & OEM & $0.229 * * *$ \\
\hline & & & & & ODM & $0.175^{* *}$ \\
\hline & & & & ODM & OEM & 0.054 \\
\hline
\end{tabular}

Mean comparison among four resource linkages in three manufacturing models

\begin{tabular}{|c|c|c|c|}
\hline \multirow{2}{*}{$\begin{array}{l}\text { Manufacturing models } \\
\text { OEM }\end{array}$} & \multicolumn{2}{|c|}{ Multiple comparisons among four resource linkages } & \multirow{2}{*}{$\begin{array}{l}\text { Mean difference } \\
-0.174^{* *}\end{array}$} \\
\hline & $\mathrm{CR}$ & PDA & \\
\hline & & MK & $0.258^{* * *}$ \\
\hline & & MDC & $0.094^{*}$ \\
\hline & & MDC & $0.268 * * *$ \\
\hline & MK & MDC & $-0.164^{* *}$ \\
\hline \multirow[t]{4}{*}{ ODM } & $\mathrm{CR}$ & PDA & $-0.138^{*}$ \\
\hline & PDA & MK & $0.250 * * *$ \\
\hline & & MDC & 0.033 \\
\hline & MK & MDC & $-0.217 * * *$ \\
\hline \multirow[t]{3}{*}{ OBM } & $\mathrm{CR}$ & PDA & $-0.173 * *$ \\
\hline & & MK & $0.127 * *$ \\
\hline & & MDC & $-0.267 * * *$ \\
\hline
\end{tabular}

Notes: $* * *$ Significant at $1 \%$ level, ${ }^{* *}$ Significant at $5 \%$ level, $*$ Significant at $10 \%$ level.

is that Taiwanese OEM firms attempt to step up value chain activities encompassing R\&D and product design in order to lessen their dependence on international brand vendors. This confirms Hypothesis 1.

Further, Table 2.2 shows that when it comes to the resource linkages made by ODM firms, the highest score is for product development ability, followed by marketing distribution channels, then cost reduction, before finally, marketing knowhow. This partly supports Hypothesis 2. It is interesting that marketing know-how is not a resource commonly sought by ODM firms (the statistical tests show that marketing know-how is significantly low when compared to the three other resource linkages), and that marketing distribution channels is the second priority resource linkage that an ODM firm seeks to establish. Perhaps Taiwanese ODM firms are more likely to employ local managers with marketing expertise from whom they can learn, therefore decreasing the need to form an alliance in order to attain marketing know-how. And it may be the desire of Taiwanese ODM firms to increase bargaining power or prepare to shift to OBM business that motivates them to seek access to marketing distribution channels. (For further discussion on this topic, please refer to Conclusions and implications section.)

Table 2.2 shows that for OBM firms, marketing distribution channels are the resource sought most often through resource linkages, followed by product development ability, then cost reduction, and finally marketing know-how. This partly supports Hypothesis 3. It is interesting that once again, marketing know-how is not a resource commonly sought by OBM firms, and product development ability is the second priority resource linkage that an OBM firm seeks to establish. This indicates that when Taiwanese OBM firms determine to establish their own brands overseas, they remain committed to manufacturing as a core competence, instead of outsourcing production to external suppliers.

\section{Conclusions and implications}

This research shows that Taiwanese manufacturing firms tend to form alliances with foreign firms based most often on the desire to access product development ability. This is true for 
the case of OEM firms and ODM firms. In the case of OBM firms, product development ability is second only to marketing distribution channels as the most sought-after resource linkage motivating alliance with foreign partners. Perhaps the reason for this focus on product development ability is that the core competence of Taiwanese firms remains to be manufacturing, so resources that enable firms to maintain or enhance this competence are valued highly and often sought out.

For OEM firms, cost reduction was the second most common resource sought, which is in line with our argument that owing to global competition and price pressure from brand vendors, careful attention must be paid to cost reduction in order to protect razor-thin profit margins.

The authors found it interesting that of the motivations for establishing a strategic alliance, marketing know-how was not a resource commonly sought by ODM firms, nor by OBM firms. We tentatively propose that when Taiwanese firms have access to international channels, they are more likely to employ local managers with marketing expertise from whom they can learn, therefore decreasing the need to form an alliance in order to attain marketing know-how.

This study also provided the interesting finding that ODM firms are moderately inclined to make resource linkages to access marketing distribution channels. It may be the desire of Taiwanese ODM firms to increase bargaining power or prepare to shift to OBM business that motivates them to seek access to marketing distribution channels.

These results have important implications for business practice. There are at least two ways in which Taiwanese ODM firms are upgrading to further ensure their longevity.

Firstly, firms may choose to shift to Own-Brand Manufacturing (OBM). Following that decision, firms generally seek to enter new markets with their own brand products. If entering a foreign market with dissimilar culture and buying habits to the home country, the firm may choose to simply employ local managers with marketing expertise in order to reduce language and cultural obstacles and to make up for their own unfamiliarity of the new market. A good example of a firm choosing to attain marketing know-how simply by employing local managers with marketing expertise, is Taiwan's Mio Technology Ltd. Local employees at its American subsidiary offered the insight to use Black Friday discount sales as an effective launching pad for the company's own brand, with the result of the company's market share for one key product category soaring to 37\% in December of 2006 (InfoTimes, 2006).

Secondly, an alternative strategy observed of Taiwanese firms is to opt against following the traditional trajectory of branching into OBM operation, but rather avoid it altogether and instead remain at the ODM stage, and then expand into other areas of business. An obvious advantage of this strategy is that the Taiwanese firm is protecting the ODM side of its business by not creating a brand that could be viewed as a competitive threat to its existing customers. In this way the firm can avoid potential loss of orders from these current vendors. One Taiwanese company that can be studied as an example is Bao Cheng Group, a key supplier for Nike Inc. When provided the opportunity to acquire an internationally famous footwear brand, Bao Cheng were aware of the potential gain, but did not want to jeopardize future business from Nike Inc. Instead, the Taiwanese firm devoted energy to establishing a strong distribution channel network (YY Sports distribution store) in mainland China, a region that is culturally similar and thus relatively accessible for Taiwanese firms but potentially hazardous for Western companies. In this way the Taiwanese firm, Bao Cheng, was able to diversify its business and increase its bargaining power without shifting from ODM to OBM business.

Many Taiwanese firms provide OEM or ODM services for international brand vendors. Through this experience these firms have developed a competitive advantage in manufacturing and often in R\&D as well. Looking at the current business model of manufacturing firms in Taiwan, more and more OEM/ ODM firms have progressed along the OEM/ODM/OBM trajectory and chosen to shift to OBM business.

One such company is Makalot Industrial Co., Ltd. Ranked by Business Week as No. 71 among Asia's fast-growing companies in 2006, the firm is a large-scale OEM/ODM supplier for several highly renowned international vendors such as GAP, Sears, Target, Du Pont, Kohl's and Walmart. In 2006, the firm established its own brand, and opened a flagship store in Taiwan's capital, Taipei and then several more retail outlets in Taiwan over the following year. Under its new OBM capacity, Makalot plans to enter mainland China over the next 2 to 3 years (Wen, 2007).

Unlike the global brand development path specified by Quelch (1999), in which global brands are always strong in their domestic market, more and more Taiwanese firms are following an alternative path by launching new brands in mainland China before releasing them in their home market. China's huge inner market and cultural similarities with Taiwan make it appealing for Taiwanese OBM firms. One such interesting case is that of Tainan Enterprises. OEM/ODM supplier to Gap, Express, and other large-scale vendors, this firm has successively launched three of its own garment brands in China since 1993. Each of the firm's brands has become very well-known in the Shanghai region and the firm's retail stores throughout China now number over 300 (Wen, 2007). Only now that the brands have achieved a certain level of success in China, has the firm begun marketing them in its home market of Taiwan.

Cultural similarities may affect the cost of branding and firmspecific knowledge is often culture related and therefore sensitive to cultural differences (Dunning \& Bansal, 1997). The cost of transferring firm-specific knowledge therefore increases with the cultural distance. Cultural difference reduces the value of any capability transferred abroad. Cultural differences also impede the formation of trust between different business units in an organization. Therefore, it makes sense that some Taiwanese firms are choosing to build their own brands in culturally-similar China.

For Taiwanese firms that choose to make the transition to OBM, the path is rife with challenges. How does one achieve complementary coexistence with vendors? As Hsu (2006) suggests, cultivating and maintaining markets while avoiding direct competition with key buyers, can indeed be difficult. 
Furthermore, what is the most effective organizational structure for Taiwanese OEM/ODM firms once they begin shifting towards OBM? How do they define the boundaries of their core competencies? Should they divest or spin off, entirely or partially, their manufacturing arms (Yeung, 2007)? These critical issues present themselves as managerial challenges to the firms of Taiwan.

\section{Limitations and future research}

Like many empirical studies, data collection involved selfreporting by single respondents, raising questions of objectivity. Additionally, our ability to make generalizations based on the results of the study is limited due to the small sample size $(N=125)$ and the fact that only Taiwanese manufacturing firms were included in the study. Another limitation is our use of yes/ no answers for the type of resources sought by Taiwanese firms. Perhaps an interval scale could enhance measurement validity. Another way to increase validity of the results would be to involve foreign partner firms in a two-sided study.

Future research could examine the co-evolution of resource linkages and manufacturing capabilities (OEM-ODM-OBM) using a longitudinal study involving in-depth interviews or case studies in order to find a causal relationship, analyzing at the same time, perhaps, factors that are likely to impact business performance, such as learning capability and organizational culture. Finally, an interesting research topic relating to Taiwanese manufacturing firms and their evolution to OBM is the question of whether a firm should build a new brand or acquire an existing one. More and more Taiwanese firms are finding success through acquiring Western brands. For example, Johnson Health Tech. Co. Ltd., a Taiwanese OEM/ODM exercise equipment manufacturer, experienced increased success after buying out its longterm vendor, EPIX, thereby acquiring its international brand name, marketing know-how, and distribution channels. Another example is the OEM/ODM bicycle manufacturer, Kenlight Trading Corp. that bought out its American customer to obtain the leading BMX bicycle brand, Haro.

\section{Acknowledgements}

The authors are indebted to three anonymous reviewers for very thoughtful and constructive comments. This research was supported by grants from the National Science Council in Taiwan (NSC-93-2416-H-002-050 and NSC-95-2416-H-002-014).

\section{References}

Andersson, U., Forsgren, M., \& Holm, U. (2002). The strategic impact of external network: Subsidiary performance and competence development in the multinational corporation. Strategic Management Journal, 23, 979-996.

Arend, R. J. (2006). SME-supplier alliance activity in manufacturing: Contingent benefits and perceptions. Strategic Management Journal, 27(8), 741-763.

Armstrong, S., \& Overton, T. (1977). Estimating non-response bias in mail surveys. Journal of Marketing Research, 14, 396-402.

Barringer, B. R., \& Harrison, J. S. (2000). Walking a tightrope: Creating value through interorganizational relationships. Journal of Management, 26(3), 367-403.
Beekman, A. V., \& Roobinson, R. S. (2004). Supplier partnerships and the small, high-growth firm: Selecting for success. Journal of Small Business Management, 42(1), 59-77.

Berger, S., \& Lester, R. K. (2005). Globalization and the future of the Taiwan Miracle. In S. Berger \& R. K. Lester (Eds.), Global Taiwan: Building competitive strengths in a new international economy: M. E. Sharpe, Inc.

Beverland, M., Napoli, J., \& Lindgreen, A. (2007). Industrial global brand leadership: A capabilities view. Industrial Marketing Management, 36(8), 1082-1093.

Business Week (2006, August 7). Interbrand annual ranking of the top 100 global brands (pp. 60-66).

Cayla, J. (2007). Asian brand without borders: Regional opportunities and challenges. International Marketing Review, 24(4), 444-456.

Chen, H., \& Chen, T. (1998). Network linkages and location choice in foreign direct investment. Journal of International Business Studies, 29(3), 445-468.

Chen, H., \& Chen, T. (2002). Asymmetric strategic alliance: A network view. Journal of Business Research, 55, 1007-1013.

Chen, H., \& Chen, T. (2003). Governance structures in strategic alliances: Transaction cost versus resource-based perspective. Journal of World Business, 38(1), 1-14.

Chen, T., Chen, H., \& Ku, Y. -H. (2004). Foreign direct investment and local linkages. Journal of International Business Studies, 35, 320-333.

Chen, S. H., Wen, P., Liu, M. C., \& Lin, X. W. (2006). Innovation capabilitybuilding and technology branding: From OEM/ODM to OBM. Paper prepared for the 2006 International Conference on Industrial Technology Innovation Repositioning for Industrial Growth and Economic Prosperity through Innovation. Taipei: Chung-Hua Institution for Economic Research.

Chen, C. W., Shen, C. C., \& Chiu, W. U. (2007). Marketing communication strategies in support of product launch: An empirical study of Taiwanese high-tech firms. Industrial Marketing Management, 36(8), 1046-1056.

Cheng, J. M. S., Blankson, C., Wu, Paul C. S., \& Chen, Somy S. M. (2005). A stage model of international brand development: The perspectives of manufacturers from two newly industrialized economies - South Korea and Taiwan. Industrial Marketing Management, 34(5), 504-514.

Crossan, M., \& Inkpen, A. (1995). The subtle art of learning through alliances. Business Quarterly, 60(2), 68-78.

Doz, Y., \& Hamel, G. (1998). Alliance advantage: The art of creating through partnering. Boston, MA: Harvard Business School Press.

Douglas, S. P., Craig, C. S., \& Nijssen, E. J. (2001). Executive insights: Integrating branding strategy across markets: Building international brand architecture. Journal of International Marketing, 9(2), 97-114.

Dunning, J., \& Bansal, S. (1997). The cultural sensitivity of the eclectic paradigm. Multinational Business Review, 5(1), 1-16.

Dussauge, P., Garrette, B., \& Mitchell, W. (2000). Learning from competing partners: Outcomes and durations of scale and link alliances in Europe, North America and Asia. Strategic Management Journal, 21, 99-126.

Dyer, J. H., \& Singh, H. (1998). The relational view: Cooperative strategy and sources of interorganizational competitive advantage. Academy of Management Review, 23, 660-679.

Eng, Teck-Yong (2005). The effects of learning on relationship value in a business network context. Journal of Business-to-Business Marketing, 12(4), 67-101.

Ernst, D. (2000). Inter-organizational knowledge outsourcing: What permits small Taiwanese firms to compete in the computer industry? Asia Pacific Journal of Management, 17(2), 223-255.

Ernst, D. (2006). Upgrading through innovation in a small network economy: Insights from Taiwan's IT industry. Paper presented at international conference "High Tech Regions 2.0 - Sustainability and Reinvention". SPRIE, Stanford University.

Glaister, K. W., \& Buckly, P. J. (1996). Strategic motives for international alliance formation. Journal of Management Studies, 33, 301-332.

Gomes, L., \& Ramaswamy, K. (1999). An empirical examination of the form of the relationship between multinationality and performance. Journal of International Business Studies, 30(1), 173-188.

Hakansson, H., \& Snehota, I. (1995). Developing relationships in business networks. London: Routledge.

Hamel, G. (1991). Competition for competence and inter-partner learning within international strategic alliance. Strategic Management Journal, 12, 83-103. 
Hobday, M. (1995). In E. Elgar (Ed.), Innovation in East Asia: The challenge to Japan.

Hobday, M. (2000). East versus Southeast Asia innovation systems: Comparing OEM- and TNC-led growth in electronics. In L. Kim \& R. R. Nelson (Eds.), Technology, learning, and innovation - Experiences of newly industrializing economies (pp. 129-169). Cambridge: Cambridge University Press.

Holm, U., Holmstrom, C., \& Sharma, D. (2005). Competence development through business relationships or competitive environment? - Subsidiary impact on MNC competitive advantage. Management International Review, $45,197-218$.

Hsu, J. -Y. (2006). Review on global Taiwan: Building competitive strengths in a new international economy. Economic Geography, 82(2), 219-220.

Huang, C. -W., \& Lo, C. -P. (2003). Using postponed manufacturing to reconfigure the supply chain in the desktop personal company industry: The case of Taiwan. International Journal of Management, 20(2), 241-246.

InfoTimes (2006, December 11). Mio technology achieves 37\% market share in U.S. black Friday sales. InfoTimes www.infotimes.com.tw

Inkpen, A. (1998). Learning and knowledge acquisition through international strategic alliances. Academy of Management Executive, 12(4), 69-80.

Jan, T. -S., \& Hsiao, C. -T. (2004). A four-role model of the automotive industry development in developing countries: A case in Taiwan. Journal of the Operational Research Society, 55, 1141-1155.

Kim, K., \& Park, J. -H. (2002). The determinants of value creation for partner firms in the global alliance context. Management International Review, 42(4), 361-384.

Kotler, P., Fahey, L., \& Jatuscripitak, S. (1985). The new competition. Englewood Cliffs. NJ: Prentice-Hall.

Li, P. P. (2003). Toward a geocentric theory of multinational evolution: The implications from the Asian MNEs as latecomers. Asia Pacific Journal of Management, 20(2), 217-242.

Luo, X., \& Homburg, C. (2007). Neglected outcomes of customer satisfaction. Journal of Marketing, 71(2), 133-149.

Mathews, J. A. (1997). A Silicon Valley of the East: Creating Taiwan's semiconductor industry. California Management Review, 39(4), 26-54.

Murray, J. Y., \& Kotabe, M. (2005). Performance implications of strategic fit between alliance attributes and alliance forms. Journal of Business Research, 58, 1525-1533.

Myers, J., Pickersgill, A., \& Metre, E. (2004). Steering customers to the right channels. McKinsey Quarterly, 4, 37-47.

Nohria, N., \& Garcia-Pont, C. (1991). Global strategic linkages and industry structure. Strategic Management Journal, 12, 105-124.

Porter, M. E., \& Baden-Fuller, M. (1986). Coalitions and global strategy. In M. E. Porter (Ed.), Competition in global industries. Boston MA: Harvard Business School Press.

Prahalad, C. K., \& Hamel, G. (1990). The core competence of the corporation. Harvard Business Review, 68(3), 79-91.
Quelch, J. (1999). Global brands: Taking stock. Business Strategy Review, 10(1), $1-14$.

Veugelers, R. (1995). Alliances and the pattern of comparative advantages: A sectoral analysis. International Business Review, 4, 213-231.

Vorhies, D. W., \& Morgan, N. A. (2005). Benchmarking marketing capabilities for sustainable competitive advantage. Journal of Marketing, 69(1), 80-94.

Wee, C. -H. (1994). National branding strategies and economic development: Implications for NIEs and LDCs. The International Executive, 36(2), 119-145.

Wen, H. (2007). The challenge of reform: How does Taiwan's textile industry shift from OEM/ODM to OBM? Taiwan Money Weekly, 361, 62-63.

Wong, P. K. (1999, June 9-12). National innovation systems for rapid technological catch-up: An analytical framework and a comparative analysis of Korea, Taiwan and Singapore. Paper presented at the DRUID Summer Conference on National Innovation Systems. Industrial Dynamics and Innovation Policy, Rebild, Denmark.

Yeung, H. W. -C. (2007). From followers to market leaders: Asian electronics firms in the global economy. Asia Pacific Viewpoint, 48(1), 1-25.

Yoshino, M. Y., \& Rangan, U. S. (1995). Strategic alliances: An entrepreneurial approach to globalization. Cambridge, MA: Harvard University Press.

Yue-Ming, S. W. (2005). Inter-organizational network and firm performance: The case of the Bicycle industry in Taiwan. Asian Business \& Management, $4(1), 67-91$.

Chia-Wen Hsu is a Ph.D. student at the Department of International Business, National Taiwan University and also a lecturer at the Department of International Business, Yuan-Ze University. His research interests include strategy management and international business.

Homin Chen is a professor at the Department of International Business, National Taiwan University. His research interests include international business and international marketing strategy. He has published in journals such as Journal of World Business, Journal of Business Research and Journal of International Business Studies.

Lichung Jen is an associate professor at the Department of International Business, National Taiwan University. His research interests include database marketing, and marketing strategy. He has published in journals such as Marketing Letters, Journal of American Statistics Association and Journal of Business \& Economic Statistics. 